\title{
ヒトの脚パワーと力・速度要因
}

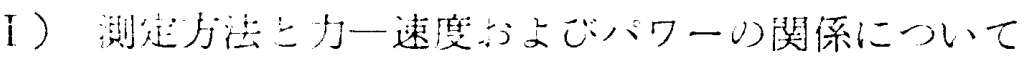

$$
\text { 川初清 典* 猪 飼 道 夫* }
$$

（昭和40年11月1日受付）

\section{The Development of the Mechanical Power and the Force-Velocity Relation on the Human Leg Extensor}

\author{
Kiyonori Kawahatsu and Michio Ikai \\ (School of Education, University of Tokyo,)
}

荷重目荷装置を作製して，滕関節伸展時の力と速度およびパワーを涀定した。湘定は，一般成人男女（23名）

について行ない, 更に, 運動選手てついて, その特性を調へた. その粘果, 力一速度関係は Hill の特性式を满 足した。運動選手についてみると，走種目競技者では，速度一力関係扰よび仕事率一力閏係とると，短距離選手

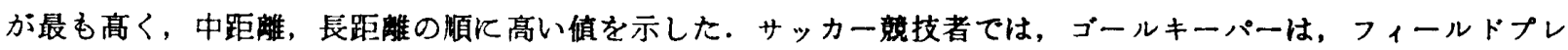
ーヤーよりも高いパワーを示し，力一速度関係も高い值を示した．このよ5に，運動選手の脚の力一速度関係は 運動種目の特性を示すことが認められた，又，最大パワーは，最大筋力の30〜 40\%の負荷で，更飞最大速度の 29 〜36\%の条件で得られた。

The characteristic relation between force and velocity was studied by isotonic lever-pulley system against the different load in human leg extensor muscle. The velocity of the lower leg extension was calculated from angular velocity by the electrogoniometer and the force was measured with straingauge tensiometer. The results were as follows:

1. As the velocity of the lower leg extension decreased with the increase of load, the force-velocity relation was presented by a hyperbolic curve as shown in the arm flexor.

2. This relation was fitted to Hill's equation except a range of the maximum velocity in adult females.

3. The mechanical power calculated from the force-velocity relation showed the maximum at approximately $30-40 \%$ of the maximum strength and at $29-36 \%$ of the maximum velocity.

4. The maximum velocity was $4.30 \mathrm{~m} / \mathrm{sec}$ for adult males and $4.22 \mathrm{~m} / \mathrm{sec}$ for adult females in average. The maximum strength was $67.8 \mathrm{~kg}$ for males and $42.4 \mathrm{~kg}$ for females. The maximum mechanical power was $41.7 \mathrm{kgm} / \mathrm{sec}$ for males and $22.6 \mathrm{kgm} / \mathrm{sec}$ for females.

5. The force-velocity relation in athletes showed specific pattern, that is to say, the curve for sprinter showed further higher pattern than that for middle and long distance runners. In the football player, goalkeeper showed also higher curve than the field players.

(Kawahatsu, Kiyonori and Michio Ikai: The development of the mechanical power and the force-velocity relation on the human leg extensor, Research Journal of Physical Education, Vol. 16, No.4, December, 1971, pp. 223 232.)

\footnotetext{
* 東京大学
} 


\section{緒}

人体の運動は，筋収縮に上る力に上つて起こさ れ，スピードを生ずる。ある運動では，スピード は小さいが，大きな力が発揮され，またある運動 では, 逆にスピードは大きいが, 小さな力しか発 捙できない。

このような筋収縮の力とスピードの関係には， 古る一定の法則性が潜んでいる. 重いものを持ち あげるには大きな力を要しながらも，大きなスピ 一ドは出せない。軽いものに対してはこの逆にな る.

このような力とスピードの関係をもとに，筋収 縮機構の䂙究をはじめたのはA.V. Hill (1922)》 であるが，力対速度の関係か门淔線関係ではなく」 「化学的エネルギーによつて説明することの必要 性」を最初に指摘したのは Fenn, W.O. (1935) である．等張力性収縮を起こした場合の筋力と筋 短縮速度の関係について Fenn, W.O. と Marsh, B.S. (1935)4) は, 力 (W) と, 速度 (V) の関係 (Force-Velocity Relationship) が, 次の指数関 係になることを示した。

$$
\mathrm{W}=\mathrm{Woe}^{-a v}-\mathrm{KV}
$$

但し, W は筋力, Wo は等尺性最大筋力, $\mathrm{V}$ は筋 収縮速度, $\mathrm{a}$ 扰よび $\mathrm{k}$ は定数.

そして先に，A.V.Hill (1922) がか提唱した粘 性理論を改めて、「エネルギーが動員される速度 が異る」と説明したのである.

A.V. Hill ${ }^{8)}$ は，1938年，カェルの摘出筋に荷 重負荷法を適用し，等張力性収縮時の熱発生を調 へ，短縮速度 $(\mathrm{V})$ と荷重または力 $(\mathrm{P})$ の関係が， 次のよ5な直角双曲線の式でよく表かされること を見出した。すなわち，

$$
(\mathrm{P}+\mathrm{a})(\mathrm{V}+\mathrm{b})=(\mathrm{Po}+\mathrm{a}) \mathrm{b} \quad(\text { 一定 })
$$

但乙Pは荷重, Vは筋短縮速度, Poは等尺性最大 筋力, $\mathrm{a}$ およびbは定数.

この式は Hill の特性方程式 (characteristic equation）と呼ばれる.

この Hill の特性式と人体筋の力一速度関係汇 ついて行なつた研究には, Ralston, H. J. et. al. (1949) ${ }^{17)}$ の，上肢切断術をほとここした患者の大胸 筋についてのむの，おょびWilkie, D.R. (1950)1)
の上腕届筋群についてのものが南る。さらに，金 于 $(1970)^{13), 16)}$ が同しく上腕㞑筋群汇ついて行な

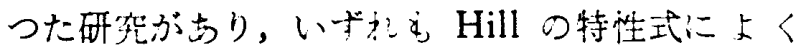

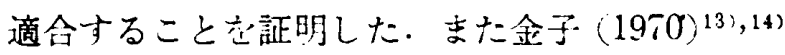
は, 力と速度の関係から，パワー（力×速度）発 生の法勋性と要因の分析を進めた。

ヒトの脚筋パワーに関しては，体育の分野で， Sargent, D.A. (1921) ${ }^{18)}$ が垂直跳テストを考案し たをそれ性後に，パワーテストとして発展してい くことになるが，この当時はまだ脚筋パワーとい 5見方はしておら当，身体能力という観点から， 筋力, 速度, エネルギー, 器用さ等をみていた。 その後 Sargent, L.W. (1924)191 はここ就仕事 最よりもむしろ仕事率を評価するテスト法である

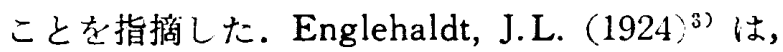
サージェントジャンプを「15秒間の跳躍高入体重 /身長」の上5に修正し，比較的長い時間になさ れる仕事といら取り扱いを行なつたままたDalen， D. V. $(1940)^{2)}$ は，垂直跳か，体重とい5固定し た負荷のみに対して行なら運動であることの短所 を，ダンベルを持たせて跳ばせることによつて補 い，負荷を変化させたときのパワーをみている。 さらにDalenは，跳びあがつたときに，使用しな い側の腕は，下にさげたままあるいは，両手を 腰に当てて跳躍し，その跳躍高から，身長をさし 引いた值を用いる等の修正を行つた。また Gray たち $(1962)^{5), 6)}$ は簡便に, 垂直跳のパワーを計算 する方法を示した。

仰卧智において，小林 $(1961)^{15)}$ は，負荷を上 から吊して，全脚の伸展に上ってこれを水平方向 ヘキックさせ，そのときのパワーを求めた。また 泚川たち $(1968)^{20}$ は，自転車エルゴメーターを用 いて脚パワーを測定し，その方法を示した。

これらの方法による脚パワーの測定は，いずれ も運動に参加する筋群や，運動様式が相違するか ら，Hill の特性式に直接照らし合わせるには困難 である.

いわゆる「力ー速度関係」は，等張力性収縮 （すなううち等速度）の条件下で，同一時点で発生 した力子速度を照合する必要がある.

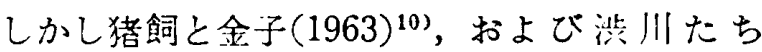
(1968) 20)の謴性車輪に上る研究では，等張力性状 


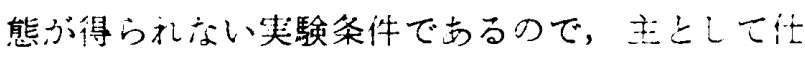

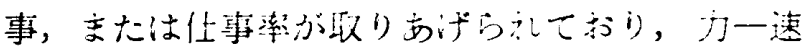

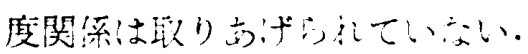

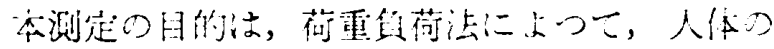

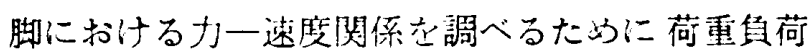
装犆定作製し，力一速度関係および脚パワーを湘

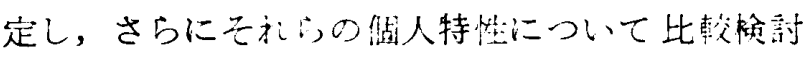
することである。

\section{測 定 方 法}

筡老等出，力一速度阅係（Force-Velocity Relationship）壳調べるのに適した荷重負荷法によつ

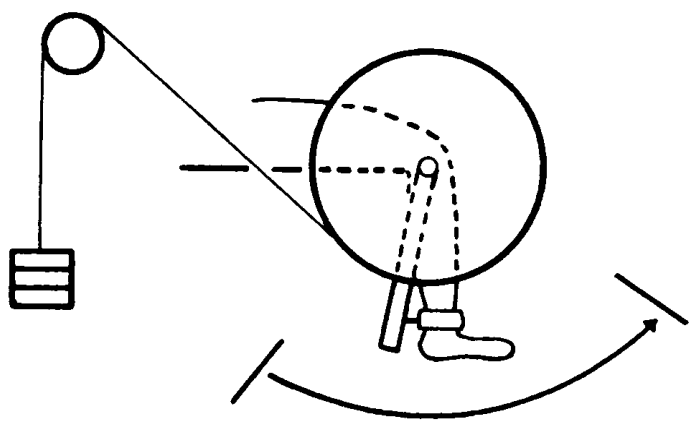

図 1 測定装䈯の原理困

て，脚パワーを测定するために，四1に示すよう な測定装置を作製した。それは滑車を介して荷重 を持ちあげる方法である。滑車の半径は $30 \mathrm{~cm}$ の むのを用い，その材質は慣性質量の小さい市販の ベニア板（12mm 厚）を用い，これにレバーをと りつけ，被検者の足頝部にはめるょうにした。

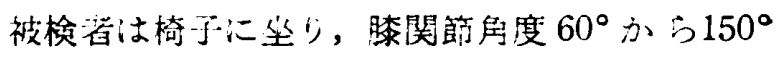
まで，最大努力で滕関節を伸展する。このときレ パーは脚(足預部)に引か妃て滑車を回枟させ る. この際に滑車の周上に， ワイアーケーブルが 巻かれて困1のよ5に荷重を引きあげる仕組であ る、滑車の軸にエレクトロゴニオメーターを装着 し，解変售一眭閻曲線を記绿した。こ㣗により角 速度おょび力が作用する足䅡部の 楾速度（脚伸展 速度）袁算出した。

荷重の設定は，等尺性最大筋力の $0 \% ， 10 \%$, 20\%，30\%，45\%，60\%とし，各負荷において， 速度を 6 回づつ測定し，その平均值交「脚伸展速 度」の成樍として採用した。

図 2 は，目荷が，等尺性最大筋力（Po）の $0 \%$ (Vo で示されている)，10\%，30\%，及び60\%に おける角度変化曲線を示す. 運動の後半では，直 線となり，ほぼ等速となつていると判断された。 従つて以下に述へる「力一速度関係」とは「荷重 一速度関係」と同じ意味である。

また，本測定において报つた被検者は表1に示 すとうりである.

\section{耛果}

\section{[I] カ一速度関係について}

一般成人男子13名，および一般成人女子 10 名に ついて，ここに述べた方法で，速度および力を湘 定した。表 2 には男子についての值を示し, 表 3

表 1 本測定で报った被検者と主な測定内容

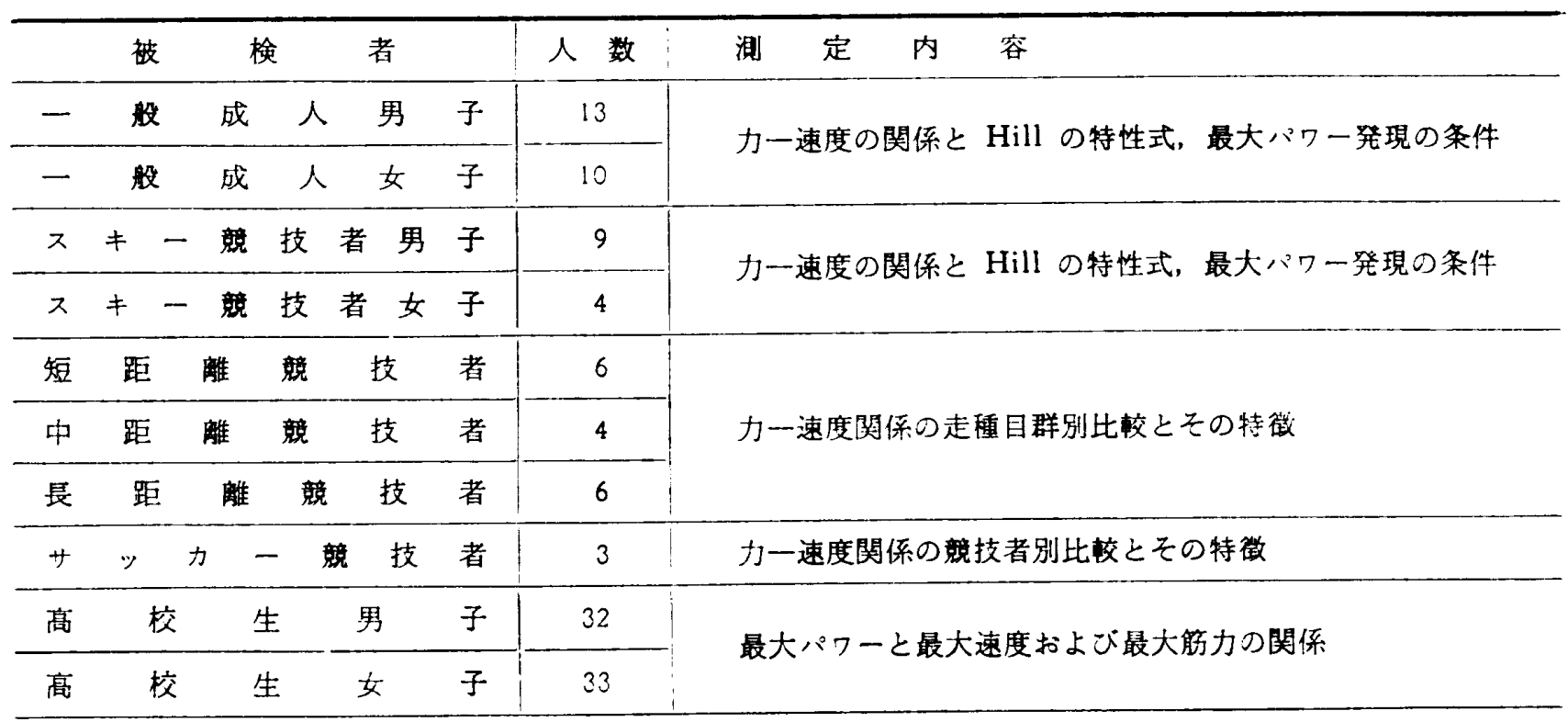




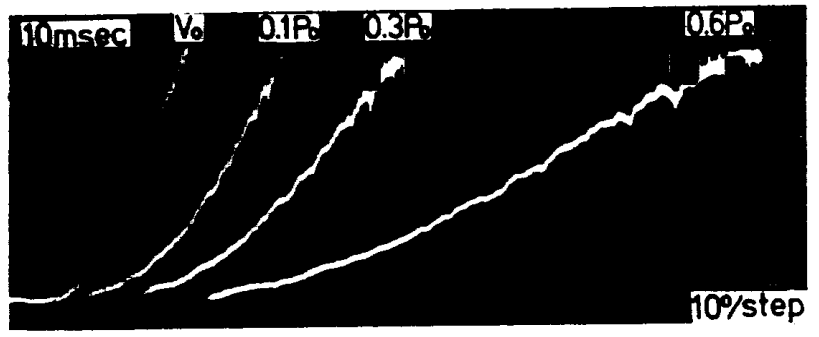

図 2 争变位一時間曲線

Voは無目荷を示し，Poは等尺喈大筋力を示す。

表 2 一般成人男子の力・速度及びパワー ( $\mathrm{P}=$ 力, $\mathrm{V}=$ 速度, $\mathrm{PV}=$ パワ一, $\mathrm{P}_{0}=$ 等尺性最大筋力であり以下同様)

Adult male

$(\mathrm{N}=13)$

\begin{tabular}{|c|c|c|c|}
\hline $\mathrm{P} / \mathrm{P}_{0} \times 100$ & $P(k g)$ & $\mathrm{V}(\mathrm{m} / \mathrm{sec})$ & 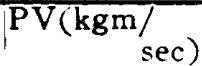 \\
\hline $0 \%$ & 0 & 4. 30 & 0 \\
\hline 10 & 6.79 & 2.65 & 18.00 \\
\hline 20 & 13. 57 & 2.19 & 25.66 \\
\hline 30 & 20.35 & 1.79 & 36.33 \\
\hline 45 & 30.53 & 1.26 & 38.34 \\
\hline 60 & 40.70 & 0.83 & 33.95 \\
\hline$P_{0}$ & 67.84 & & \\
\hline
\end{tabular}

表 3 一般成人女子の力・速度及びパワー Adult female

$(\mathrm{N}=10)$

\begin{tabular}{|c|c|c|c|}
\hline$P / P_{0} \times 100$ & $P(k g)$ & $\mathrm{V}(\mathrm{m} / \mathrm{sec})$ & $\mathrm{PV}(\mathrm{kgm} / \mathrm{sec})$ \\
\hline $0 \%$ & 0 & 4. 22 & 0 \\
\hline 10 & 4.23 & 2.43 & 10.30 \\
\hline 20 & 8.46 & 2.09 & 17.64 \\
\hline 30 & 12.69 & 1.66 & 21.07 \\
\hline 45 & 19.03 & 1.19 & 22.57 \\
\hline 60 & 25.39 & 0.82 & 20.69 \\
\hline$P_{0}$ & 42.40 & & \\
\hline
\end{tabular}

には女子についての值を示した。また，表 2、お よび表 3 の做から図 3 が得られる。表 2 および表 3 の做から，力一速度の関係を求めると次のよ5 になる。

男子: $(\mathrm{P}+60.83)(\mathrm{V}+3.47)=437$

女子: $(P+50.47)(V+3.54)=331$

但し，P注荷重，Vは速度を示す。

図3に示与双喵線状の明線は，この力一速度の 関係式に基ついて得られたもので苛る。测定值は 男女とも，船負荷の状態に抢ける脚伸展速度（Vo で表わさ礼，最大速度と同じ意味で古る）を除

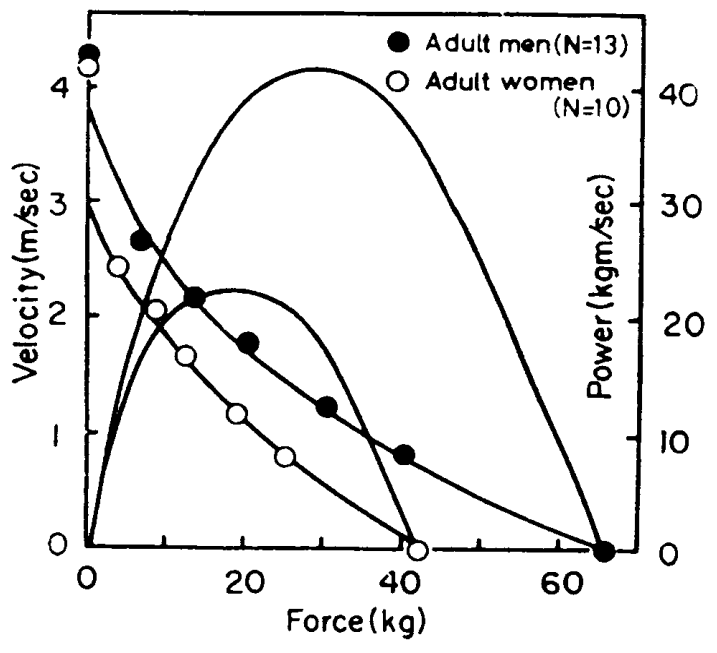

図 3 一般成人男子及び女子の力一速度曲線及 びパワー曲線

（直角双曲線は力一速度，凸状曲湶はパ ワー曲線を示し，以下同様である）

き，Hill の特性式によく適合した。

無负荷の状態に扮汁る脚伸展速度では，男子か $4.30 \mathrm{~m} / \mathrm{sec}$ ，女子尔 $4.22 \mathrm{~m} / \mathrm{sec}$ であり，その男女 比は，98.2\%となつて，殆んど性差が認められな い.しかし，負荷（すなわち力）が增加するに二 れて，脚伸展速度の男女差が大きくなる。そし て，等尺性収縮に和ける最大筋力（Po）では，具 子が $67.84 \mathrm{~kg}$ ，女子が $42.40 \mathrm{~kg}$ となつて，女子の 男子に対する比は $62.5 \%$ となつた。

次に, 脚の力一速度関係について, 現在, 競技 者である男子および女子を対象に測定し，一般成 人との比較を試みた。被検者は，スキー種目筫子 9名，および女子 4 名である.

これらスキ一競技者の，力一速度関係曲線，扎 よび仕事率一力関係曲線は図4 に示す通りになこ た。

最大速度（無色荷に抢ける速度）では，男子競 技者 9 名の平均值が $5.68 \mathrm{~m} / \mathrm{sec}$ ，女子競技者 4 名 の平均值が $6.18 \mathrm{~m} / \mathrm{sec}$ となつて，女子競技者の力 が高い值を示した、久，等尺性最大筋力では，照 子競技者の平均值が， $83.3 \mathrm{~kg}$ ，女子競技者の平坽 值が $57.5 \mathrm{~kg}$ であつた。

これら最大速度，およで最大筋力は，とをに一 般成人の值を大きく上まわるものである。

また，力一速度の関係については，次の上5に なつた。 


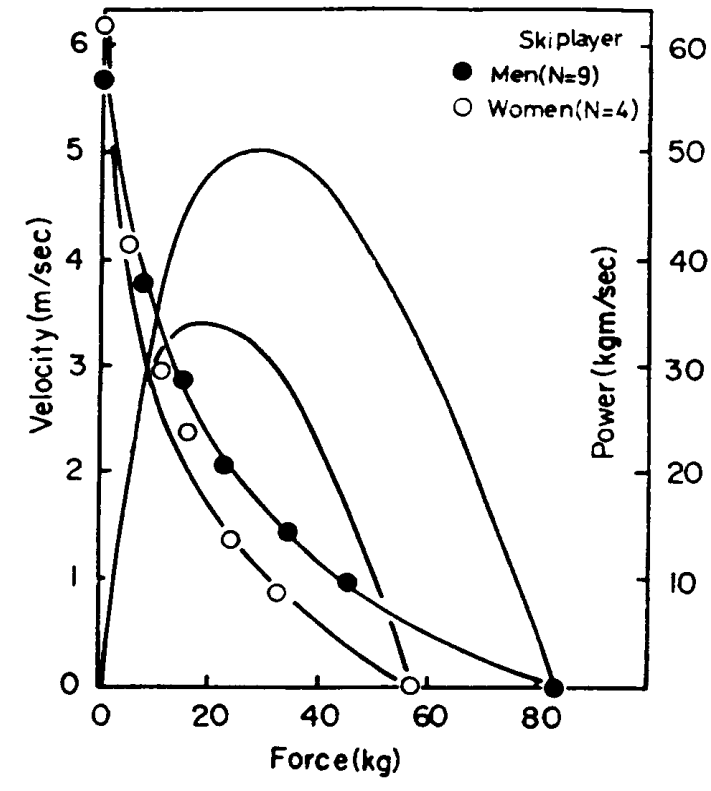

図4 スキ一選手の力一速度曲線及びパワー曲線

男子: $(\mathrm{P}+24.1)(\mathrm{V}+1.65)=177.5$

女于: $(P+15.5)(V+1.67)=121.9$

但l, Pは荷重, Vは速度.

因 4 の双曲線は上式から求めたものである。一 般成人の場合には，無負荷における脚伸展の際 に，奏験式（Hill の持性式）に適合しない值がみら

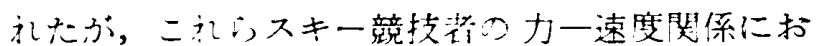

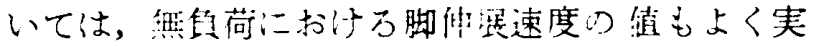
験式に碑心した。

\section{〔II〕樶大パワー（取大壮事事）について}

一般成人男子，扣上び一般成人女子の測定結果 について，最大パワー発現の条件を，力および速 度の面から調べた。

力一速度の関係か：Hill の持性式を満足方る場 合, その式から, 力 $(\mathrm{P})$ とパワー(PV)の関係は, 次の上うになる。

$$
\mathrm{PV}=\mathrm{bp}\{(\mathrm{Po}+\mathrm{a}) /(\mathrm{P}+\mathrm{a})-1\}
$$

Hill $(1938)^{9)}$ に上ると，パワーが最大となるとき の力 $(\mathrm{P})$ を求めるために $\mathrm{dpv} / \mathrm{dp}=0$ とおいて(1)式 を微分すると

$$
\mathrm{p} / \mathrm{a}=\sqrt{1+\mathrm{Po} / \mathrm{a}}-1
$$

となる，そこで测定值，P，Po，および定数 $\mathrm{a}$ を 代入した結果，一般成人については，表 4 が得ら れた。表 4 から，一般成人男子の最大パワーは， 負荷（力）か： $27.3 \mathrm{~kg}$ （等尺性最大筋力の $40.3 \%$ ) のとき， $41.7 \mathrm{kgm} / \mathrm{sec}$ となり，最大を示した。同 様に，一般成人女子では，負荷が $17.9 \mathrm{~kg}$ （等尺

表 4 最大パワーと力および速度の条件（一般成人）

\begin{tabular}{c|c|c|c|c|c|c}
\hline \multirow{2}{*}{ Subjcte } & $\mathrm{N}$ & $\mathrm{PV} \underset{\mathrm{max}}{\mathrm{mgm} / \mathrm{sec})}$ & \multicolumn{2}{|c|}{$\mathrm{P}$} & \multicolumn{2}{c}{$\mathrm{V}$} \\
\hline Male & 13 & 41.7 & $\mathrm{~kg}$ & $\%$ of max. & $\mathrm{m} / \mathrm{sec}$ & $\%$ of max. \\
\hline Female & 10 & 22.6 & 27.3 & 40.3 & 1.54 & 36.0 \\
\hline
\end{tabular}

性最大筋力の $42.4 \%$ ）のとき $22.6 \mathrm{kgm} / \mathrm{sec}$ となり 最大となつた。

このよ5に一般成人の測定においては，男女と も, 貞荷（力）が最大筋力の $40 \%$ 付近において, 最大パワーが得られた。そのと产の脚伸屡速度 は，表 4 に示される如く，男子では $1.54 \mathrm{~m} / \mathrm{sec}$ で，最大速度(無負荷に拈汁る脚伸展速度)の36.0
\%，女子では $1.26 \mathrm{~m} / \mathrm{sec}$ となり，最大速度の 29.9 \%であつた. 最大パワーが得られる際の速度を最 大速度と比較すると，その割合が，男子よりも女 子の場合に低いのは，女子の無目荷における速度 が，比較的高いことによつている。また女子の最 大仕事率は男子の值の $54 \%$ であつた。

次に，スキー競技者の最大パワー発現に関して

\begin{tabular}{|c|c|c|c|c|c|c|}
\hline \multirow{2}{*}{ Subject } & \multirow{2}{*}{$\mathrm{N}$} & \multirow{2}{*}{$\mathrm{PV} \max _{(\mathrm{kgm} / \mathrm{sec})}$} & \multicolumn{2}{|c|}{$\mathrm{P}$} & \multicolumn{2}{|c|}{$\mathrm{V}$} \\
\hline & & & $\mathrm{kg}$ & $\%$ of max. & $\mathrm{m} / \mathrm{sec}$ & $\%$ of $\max$. \\
\hline Male & 9 & 46.9 & 26.7 & $32 .:$ & 1.75 & 30.9 \\
\hline Female & 4 & 33.6 & 18.1 & 31.5 & $\div .85$ & 29.9 \\
\hline
\end{tabular}

表 5 スキ一選手の最大パワーと力および速度の条件 
第 4 号 昭和 47 年1月

闰じょうここの条件を調べた結果ぶ表 5 である。 表 5 か心男子競技者の場合には，等尺性最大筋力

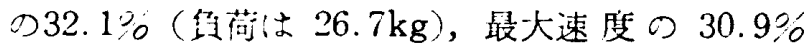
（速度は $1.75 \mathrm{~m} / \mathrm{sec）のときに} 46.9 \mathrm{kgm} / \mathrm{sec}$ と なつて最大な示した。また女子競技者の場合に は, 等尺性最大筋力の $31.5 \%$ (負荷は $18.1 \mathrm{~kg}$ ), 最大速度の $29.9 \%$ （速度は $1.85 \mathrm{~m} / \mathrm{sec}$ ）のときに $33.6 \mathrm{kgm} / \mathrm{sec}$ となつて最大を示した。

\section{［III］競技者の力一速度関係およびパワー曲線 の特徽}

陸上競技の走種目の競技者については，種目群 を走行距離から区分した。すなわち $100 \mathrm{~m}$ から $400 \mathrm{~m}$ までの種目の競技者を短距離群とし， $800 \mathrm{~m}$ から $1500 \mathrm{~m}$ までの競技者を中距離群とし，5000m 以上の距離の競技者を長距離群とした。本测定で は, 短距離群 6 名, 中距離群 4 名, 長距離群 6 名 について行なつた。

これらの競技者が，脚伸展運動を最大努力で行 なつた際の力一速度関係および仕事率一力関係を 四に示した。さらに，最大速度（無負荷の状態に 扣ける脚伸展速度 $\mathrm{Vo}$ ), 最大筋力（等尺性収縮に よる最大筋力 $\mathrm{Po}$ )，および最大仕事率 PVmax. についての平均値を表 6 に示した。図 5 および表 6 によると, 最大筋力, 最大速度, および最大仕 事率のいずれにおいても, 短距離群が最大, 次に 中距離群，長距離群の順となつている。図 5 にお

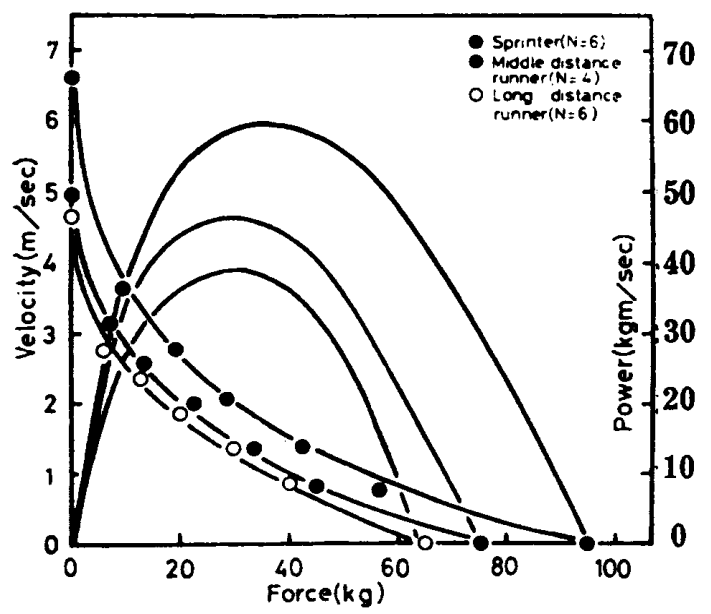

図 5 走選手の力一速度関係および仕事率一力関係 （横軸は力, 左絽軸は速度, 右縦軸は仕事率 を示し, 双曲線は力一速度関係。凸状曲湶は 仕事率一力関係を表わす）
表 6 走造手の最大筇力 $\left(\mathrm{P}_{0}\right)$ ，最大速度 $\left(V_{0}\right)$ 及び最大仕事率 (PVmax)

\begin{tabular}{l|c|c|c|c}
\hline \multicolumn{1}{c|}{ Runner } & $\mathrm{N}$ & $\mathrm{P}_{0}(\mathrm{~kg})$ & $\mathrm{V}_{0}\left(\mathrm{~m} / \mathrm{PV}_{\mathrm{sec}}\right.$ & $\begin{array}{c}\mathrm{P} \text { max } \\
(\mathrm{kgm} / \mathrm{sec})\end{array}$ \\
\hline $\begin{array}{l}\text { Sprinter } \\
\begin{array}{c}\text { Middle distance } \\
\text { runner }\end{array}\end{array}$ & 6 & 94.5 & 6.58 & 58.29 \\
$\begin{array}{c}\text { Long distance } \\
\text { runner }\end{array}$ & 6 & 65.6 & 4.66 & 40.47 \\
\hline
\end{tabular}

いて，力一速度関係を示す双曲線およびパワーー 力関係を示す放物線状の曲線は，パワーを主とす る筋運動能力における走種目競技者の種目の差を 示している。

次に，本測定法の脚伸展運動が，サッカー競技 において，球を蹴ることとよく類似した運動であ ることに注目し，力一速度関係扰よび仕事率一力 関係について調べた。被検者は, 東京大学サッカ 一部員であり, ウイング，バック，およびゴール キーパーを1名づつ選び, 競技のポシションと力 一速度関係，お占び仕事率一力関係について测定 した.としてこれらの競技者の力一速度関係およ び仕事率一力関係を図 6 に示した.さらに表 7 は, これらの競技者の身長, 体重, 最大筋力, 最大速 度, および最大パワーを示している.因6および 表 7 から，コールキーパーである被検者 INI が， 最大筋力, 最大速度, 最大パワーともに, 最も高 い値を示しており，最大パワーでは，ゴールキー

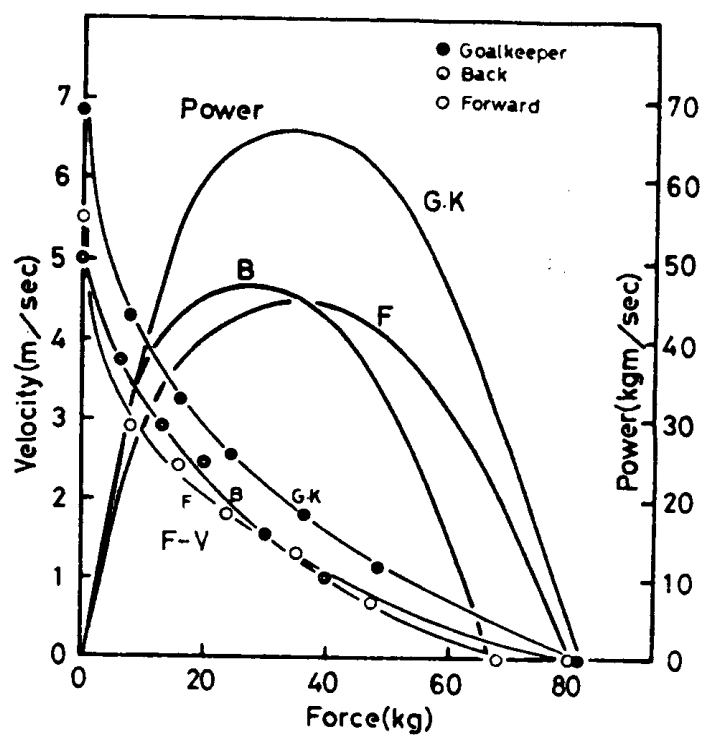

図 6 サッカー選手のポジションとカ一速度関係曲 線およご仕事率一力関係曲線（G・Kはゴー ルキーパー，Bはバック，Fはフォワード) 
门初・猪飼：ヒトの脚パワーと力・速度要因

表 $7+ッ カ ー$ 選手の身長・体重並でに，最大筋力，最大速度，および最大仕事率

(Football)

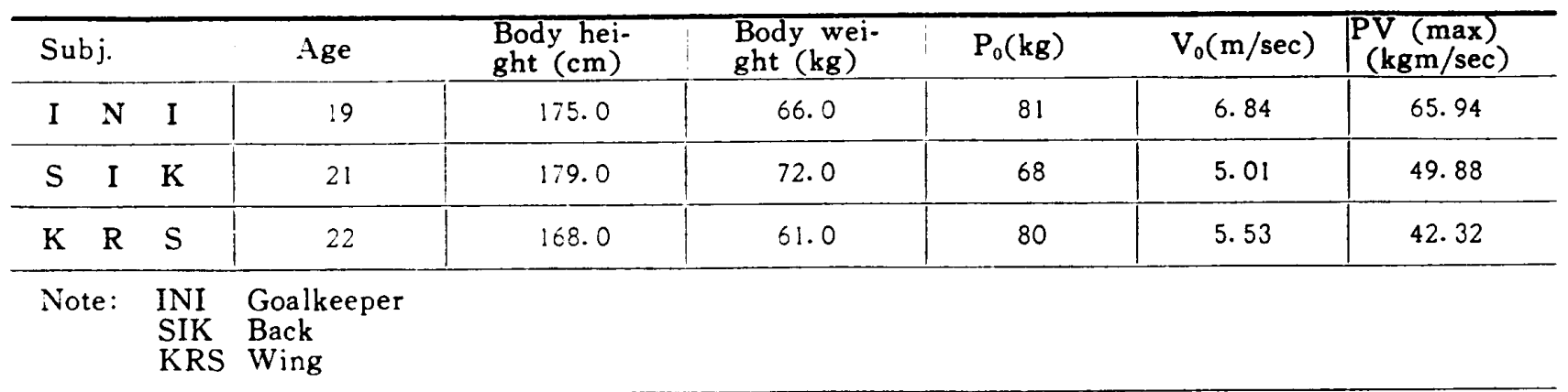

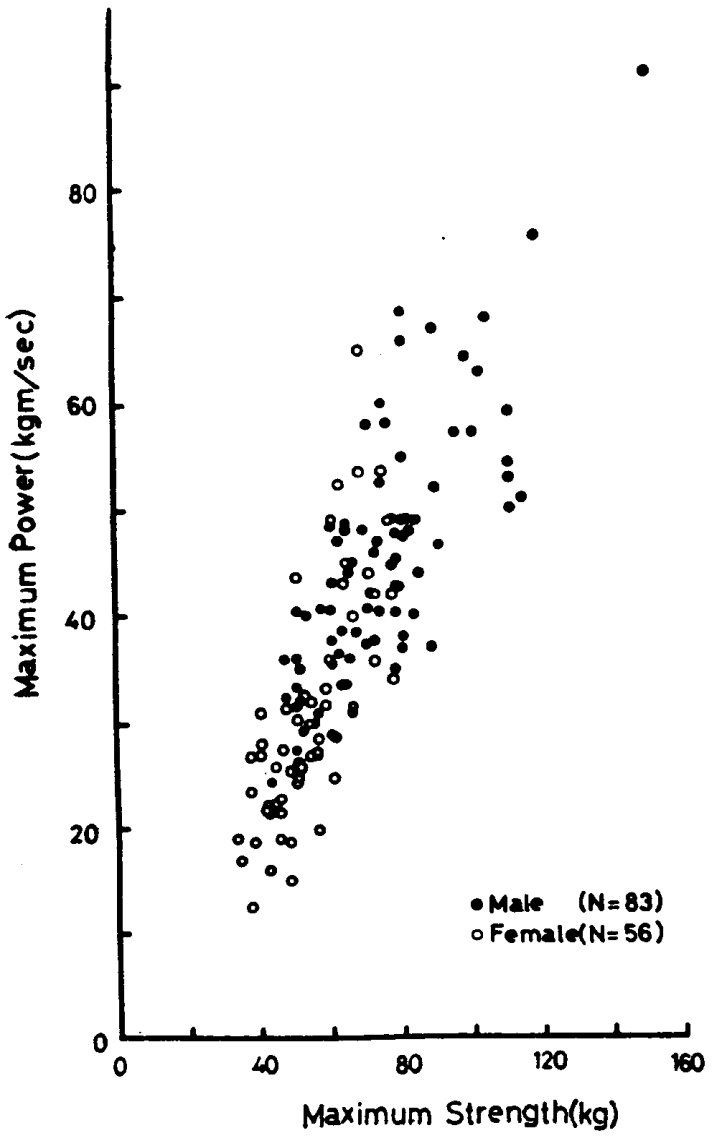

図 7 最大仕事率と最大筋力の関係

パー, ハシック，ウイングの順に高い值を示した。

これら 3 名の力一速度関係曲線および仕事率一力

関係曲線をみると，ゴールキーパーが全般にわた

つて著しく高い.このことは，ゴールキーパーの 練習内容，ゴールキーパーとして要求される適性 などが示されていると思われる。

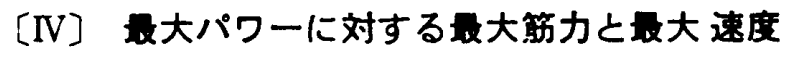
各個人の成績について，最大パワーと最大筋力 （等尺性最大筋力）の関係をみると，図 7 の如く

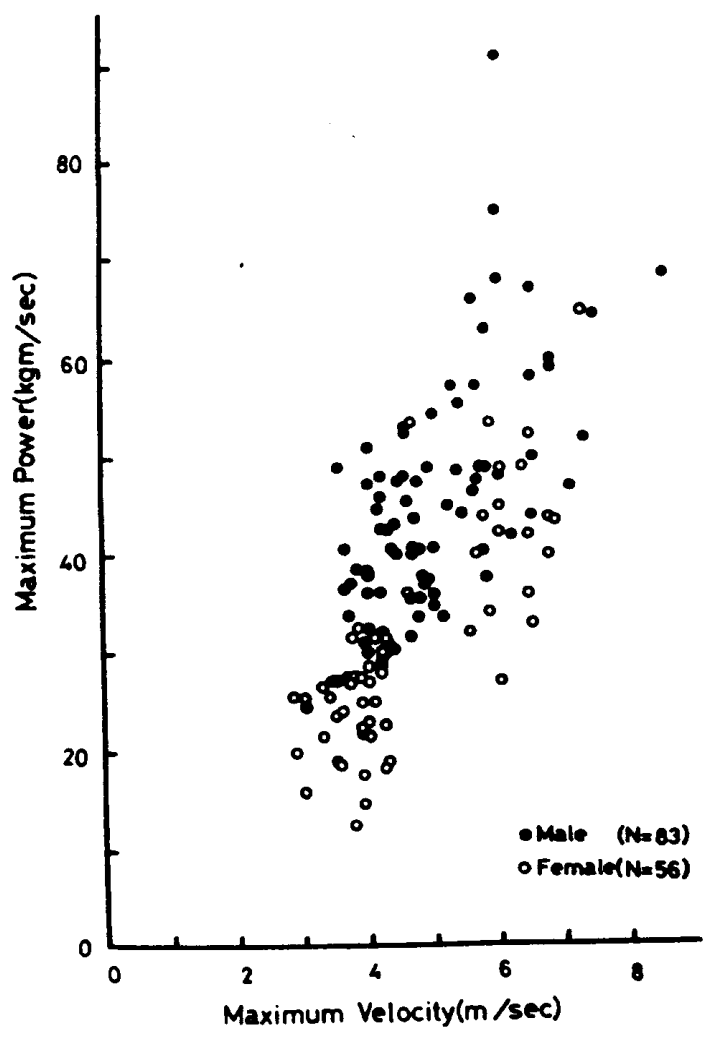

図 8 最大仕事率と最大スピードの関係

なる.この罒から, 女子 (白点) の值は, 男子(黒 点）の值と同じ筙囲に分布し，男女共に，脅力の 高い人ほどすぐれたパワ一能力をもつことを示し た。

次に，「パワーと筋力」の項で抜つたのと同一 の被検者について，最大パワーと最大速度（無真 荷の状態における速度）の関係を調へ，図 8 に示 した、困8から，白点で示される女子の值は，筋 力とパワーの項でみられた傾向とは異なつてお り，男子に比較して，最大速度では同じ程度の成 績分布を示しながら，最大パワーでは男子(黒点) よりも下まわる傾向を示している.すなわち，最 
大パワーは，鼠大速度よりもむしろ，鼠大筋力に 強く影響されていることがわかる。

\section{[V] 脚筋パワーと全身パワー}

ヒトが全身運動を行なう際に，脚のなす役割は 大変大きいので，全身が出し得るパワーと，脚パ ワーとの関係を調へてみることが必要である， R. Margaria たち $(1966)^{16)}$ は，全身無酸素性 パワー を測定するために，全力で階段を，かけあがる方 法を用いたが，本研究に扣いては，摩擦負荷を与 える自転事エルゴメーターを，全力で回転させる 方法を用いて，全身無酸素性パワーを测定した。

同一被検者について，脚パワーと，全身無酸素 性パワーの関係をみると，図 9 のようになり，脚 筋パワーがすぐれている人汪ど，高い全身性パワ 一を示している。

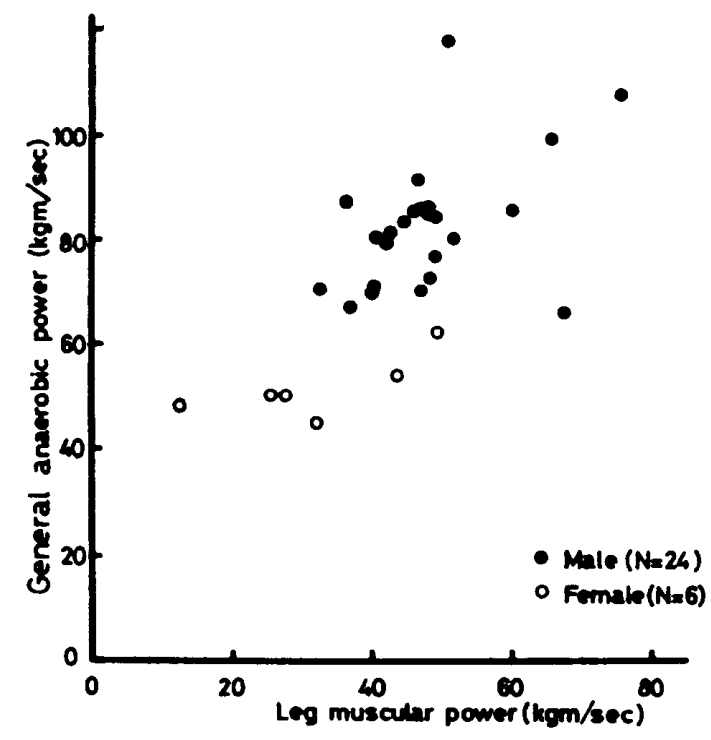

図 9 脚筇パワーと全身無酸菜性パワーの関係

\section{論}

本研究に执いては, 荷重法によつて, 脚パワー を測定する方法を確立し，更にその忘用について 示した、この方法によつて，脚力およびパワーを 測定することは勿論, 脚伸展速度と脚筋力, 脚仕 事率と脚筋力の関係を，一般成人および運動選手 について示した。

負荷が軽いときの運動は，脚目身の慣性質量の 影響を受けやすい，本测定において，四3に示さ
れる如く，一般成人では，特に女子において，䒈 負荷の状態の測定值が，力一速度の関係式に 合致 しにくい傾向があつた。しかし，運動巽手の测定 においては，無嗮荷の状態における測定值も，実 験汛（Hill の特性式）に上く一致した(四 4).

この上5に差がみられたことに関しては，無負 荷での脚伸展と Hill の特性式の関係，おょび， 下腿と大腿伸筋群の慣性質量, 荷重の運動（脚伸 展運動の際の荷重の加速度）等の条件を考㭸し て，今後さらに㭘討しなければならない。

更に，無目荷の状態に疋いて，脚伸展速度は， 男子は平均值で， $4.30 \mathrm{~m} / \mathrm{sec}$, 女子は $4.22 \mathrm{~m} / \mathrm{sec}$ となり，殆んど差をみない傾向を示したのに対 し，等尺性最大筋力では，男子が平均值で 67.84 $\mathrm{kg}$ ，女子は $42.40 \mathrm{~kg}$ となつて，女子の最大筋力 は男子のおよそ62\%であつた（一般成人の項, 表 2 , 表 3 ).

このよ5な傾向は，最大速度と最大仕事率の関 係を示した図 8 にもらられており，無負荷の状 態では，男女の間に 脚伸展速度の 差をみなかつ た. 最大速度（無目荷の状热における速度）の性 差については，金子 $(1970)^{13), 14)}$ が，人体の上腕 屈筋群における测定から, 殆んど差がない事を報 告している.

次に最大パワー（最大仕事率）の発現条件につ いて，一般成人男子の平均値 では，最大筋力の $40.3 \%$ ，同女子の平均值では最大筋力の $42.4 \% の$ 負荷において得られた。この点については A.V. Hill $(1938)^{8)}$ が最大筋力の䄪 $30 \%$ の負荷で，機 械的仕事率の最大值を得，人体の場合でもほぼ同 じであると述べたこと $(1940)^{9) ， お よ ひ ゙ ~ W i l k i e ， ~}$ D.R. (1950) ${ }^{21)}$ の研究結果にも，人体の上腕屈筋 群における実験結果から，最大筋力の約 30\%の直 荷において機械的仕事率の最大値を得ていること と比較すると，本研究ではやや高い筋力で最大仕 事率が得られている傾问を示した。

又, 短距離走競技者の平均値では, 最大筋力の $36.1 \%$ で最大仩事率を得ており，金子(1970) ${ }^{13), 14}$ が一般成人男子について，上胣屈筋群では，最大 筋力の35\%，同女子については36\%で最大仕事染? を得たと報告したことに近い值が諗められた。更 に，スキ一競技者では，男女共，最大筋力の的 30 
吕の負荷で，最大任事率が琴えれた。三して，最 大仕事率は最大速度の $29 \%$ \% 36\%の籍囲で得られ た. この速度の条件は，金子 $(1970)^{13)}$ か上腕屈 筋群について，一般成人男子が最大速度の $33 \%$ ， 女子が34\%と報告したことに近い值である。

走種目競技者については（四 5)，走行距離分 短かい種目群の競技者ほどパワーが高く, 屰に, 走行距離が長い種目の競技者ほどパワーが低いと い5結果を得た。筋連動の様式は, 走行距離が短 かい種目ほど高いパワーが要求されるところから みて, 当然の結果ともいえるが，それが本研究に よつて明らかにされたとい5ことである。

次にサッカー競技者については (図6)、ゴー ルキーパーが特に高い仕事率一力関係曲線を示し

た. Caru, B.たち $(1970)^{1)}$ も，ゴールキーパーの 無酸素性全身パワーがフイールドプレーャーより あ高いとい5結果を得て，「ウイングでは，ゲー ムにおいて常に走つており，持久的な運動が多 く、ゴールキーパーは，攻撃されたときに，瞬発 的に動けなくてはならないとい5 運動の性格が表 わされている」と述べている・ジールキーパー は，ボールを相手陣地にむかつて，出来るたけけ遠 くへ䟽りかえすトレーニングを多く行ない, 又, 強力な跳羅力が要求され，トレーニングされると いう事実が，パワー成精の優秀さの背景にあるも のと考えられる。

\section{要約}

荷重目荷装置を作彆して，最大努力に上る㮏関 節伸展時の力と速度, およびパワーを测定した。 脚伸展速度の測定は, エレクトロゴニオメーター を使用し，力の测定は，ストレインゲージ張力計 によつた。

1. 脚伸展速度は, 筋力(負荷)の增加とともに 娍少し, 力と速度の関係は淔角双曲線となつた。

2.力一速度の関係は，一般成人男子，および スキー競技者（男子および女子）では，Hill の特 性式に適合したが，一般成人女子での最大速度は これからはずれた。

3. 一般成人の测定值では, 男子13名の平均值 か，最大筋力 $67.8 \mathrm{~kg}$, 最大速度 $4.30 \mathrm{~m} / \mathrm{sec}$, 最大 パー $41.7 \mathrm{kgm} / \mathrm{sec} 亡 な り$, 女于 10 名の平均值
方, 最大筇力 $42.4 \mathrm{~kg}$, 最大景度 $4.22 \mathrm{~m} / \mathrm{sec}$, 最大 パー $22.6 \mathrm{kgm} \mathrm{sec}$ と市つた。

4. スキー競技者では，男于 9 名の平均值引， 最大筋力 $83.3 \mathrm{~kg}$, 最大速度 $5.68 \mathrm{~m} / \mathrm{sec}$, 最大バ - $46.9 \mathrm{kgm} / \mathrm{sec}$ となり, 女子 4 名の平均值が, 最大筋力 $57.5 \mathrm{~kg}$, 最大速度 $6.18 \mathrm{~m} / \mathrm{sec}$, 最大パワ 一 $33.6 \mathrm{kgm} / \mathrm{sec}$ であつた。

5. 最大パワーは，最大筋力の $30 \%$ 40\%の負 荷で, 又最大速度の $29 \%$ 36\%の条件で得られた。

6. 力一速度関係の男女差は無目荷の状態では ほ上んどなく，負荷が增加するにつれて大きくな つた.

7. 走種目競技者では, 力一速度関係曲線およ び仕事率一力関係曲線は, 短距離, 中距離, 長距. 離の順に高い值を示した.

8. サッカー競技者において，ゴールキーパー は,フイールドプレーヤーよりも大きいパワーを 示した。

9. 脚パワーは, 全身無酸菜性パワーと高い関 係にあつた。

最後，本研究にあたつて，種々の示喛を仰いだに，大 阪体育大学、金子公有助教授保、記して深く新意を表し ます。

なお本研究は，文部省科学研究費特定研究「運動制御 とその機粠」の一部として行なわれたものである.

\section{引用文献}

1) Caru, B. et al.: Maximal aerobic and anaerobic muscular power in football players. J. Sports. Med., 10, 100-103, 1970.

2) Dalen, D. V.,: New studies in the sargent jump. Res. Quart., 11, 112-115, 1940.

3) Englehaldt, J.L., : A test of physical efficiency. J. Psychol., 15, 573-578, 1924.

4) Fenn, W.O., and Marsh, B.S.,: Muscular force at different speeds of shortening. J. Physiol., 85, 227-297, 1935.

5) Gray, R.K. et al.: A test of leg power. Res. Quart., 33, (1), 44-50, 1962.

6) Gray, R.K. et al.: A useful modification of the vertical power jump. Res. Quart., 33, (2), 230-235, 1962. 
7) Hill, A.V.: The maximum work and mechanical efficiency of human muscles and their most economical speed. J. Physiol., 56,19-41, 1922.

8) Hill, A.V.: The heat of shortening and the dynamic constants of muscle. Proc. Roy. Soc. B., 126, 136-195, 1938.

9) Hill, A.V.: The dynamic constants of human muscle. Trans. Roy. Soc. B., 128, 263-274, 1940.

10）猪同式夫・金子公东，パワーの眼定. OL YMP I A, 2, 68-75, 1963.

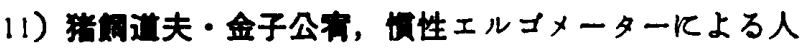
体筋パワーの湘定. 体青学研究, 8，72-82, 1965.

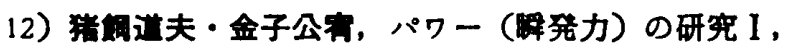
I，体青の科学，15，571-576，634-639， 1965.

13) Kaneko. M.: The relation between force, velocity and mechanical power in human muscle. Res. J. Physical Education, 14, (3), 143-147, 1970.

14）金子公雨，觔収緛の力・スピード・パワー，体青の 科学, $20,(6), 368-373,1970$.

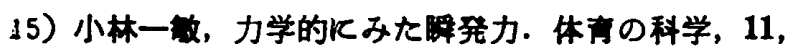

(12), 604-607, 1961.

16) Marcaria, R., et al.: Messurement of muscular power (anaerobic) in man. J. Appl. Physiol., 21, (5), 1662-1664, 1966.

17) Ralston, H.J., et al.: Dynamic features of human isolated voluntary muscle in isometric and free contraction. J. Appl. Physiol., 1, (2), 526-533, 1949.

18) Sargent, D.A.: The physical test of a man. School and Society, 13, (318), 128-135, 1921.

19) Sargent, L.W.: Some observations on the sargent test of neurommenlar efficiency. Am. Phys. Educ. Rev., 29, 47, 1924.

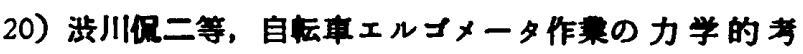

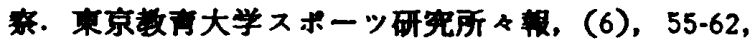
1968.

21) Wilkie, D.R.: The relation between force and velocity in human muscle. J. Physiol., 110, 249$280,1950$. 